University of Nebraska - Lincoln

DigitalCommons@University of Nebraska - Lincoln

Faculty Publications: Department of Teaching, Department of Teaching, Learning and Teacher Learning and Teacher Education

Education

8-11-2020

\title{
Language and Identity: Multilingual Immigrant Learners in South Africa
}

Saloshna Vandeyar

Theresa Catalano

Follow this and additional works at: https://digitalcommons.unl.edu/teachlearnfacpub

Part of the Bilingual, Multilingual, and Multicultural Education Commons, Curriculum and Instruction Commons, and the Teacher Education and Professional Development Commons

This Article is brought to you for free and open access by the Department of Teaching, Learning and Teacher Education at DigitalCommons@University of Nebraska - Lincoln. It has been accepted for inclusion in Faculty Publications: Department of Teaching, Learning and Teacher Education by an authorized administrator of DigitalCommons@University of Nebraska - Lincoln. 


\title{
Language and Identity: Multilingual Immigrant Learners in South Africa
}

\author{
Saloshna Vandeyar \\ https://orcid.org/oooo-0003-0195-6330 \\ University of Pretoria, South Africa \\ saloshna.vandeyar@up.ac.za \\ Theresa Catalano \\ https://orcid.org/oooo-0oo2-7519-03oX \\ University of Nebraska-Lincoln, USA \\ t.catalano2@unl.edu
}

\begin{abstract}
Increased multilingualism and mobility have witnessed an increased focus on multilingual immigrant learners. This study aims to help educators understand experiences of immigrant students in South Africa that relate to language and identity by comparing such experiences across three different school settings: an urban school with a high (Black) immigrant and indigenous population, a former Indian school, and a former White school. Drawing on semi-structured interviews from a larger case study, this study makes visible the immigrant learner experience in multilingual settings in which xenophobic conditions arise. The findings reveal similarities as well as differences in individual identity construction and negotiation and its vital connection to language. Furthermore, they illustrate ways in which these learners must navigate xenophobic trends, exclusive language pedagogies, and language loss. The implications of this study point to a call for policy, practice, and research to take into account multilingual immigrant learners as well as a need to attend to the social construction of identities.
\end{abstract}

Keywords: language and identity, multilingual immigrant learners, South Africa, xenophobia

Published in Language Matters, 51:2 (2020), 106-128

DOI:10.1080/10228195.2020.1769713

Copyright (c) 2020 Unisa Press; published by Routledge/Taylor \& Francis. Used by permission.

Published 11 August 2020. 


\section{Introduction}

Although multilingualism has always existed, today's multilingualism is different. It is wider in scale and both affects and reflects society as a whole (Aronin 2015). This expansion of multilingualism is due to the "social, linguistic and cultural changes derived from globalization, geographical and social mobility, economic and political transformations and the omnipresence of technology in all spheres of life" (Ruiz de Zarobe and Ruiz de Zarobe 2015, 393-395). As a result of this changing multilingualism which is now the norm around the world, increasing attention has been focused on multilingual learners and the ways in which they manage learning and identity negotiation in contexts in which the language/s of school are not necessarily the language/s they speak at home. South Africa (SA), in particular, has been a frequent location of study for multilingual pedagogy, given the rich multilingual environment of the country.

South Africa has a complicated history and a complex perspective on Black immigrants. ${ }^{1}$ Statistical population estimates for South Africa report the total population as $57,725,600$, of which $80.9 \%$ are Black African; 7.8\% White; 8.8\% Coloured, and 2.5\% Indian (StatsSA 2018). ${ }^{2}$ According to the 2016 census, South Africa has 2.2 million legal immigrants and close to 1 million undocumented foreign nationals (Chiumia 2016). Black immigrant learners can be classed into two groups. The majority of Black immigrant learners are either English or French second- or third-language learners, depending on the colonisation process of their respective countries across the African continent. Many of these immigrants still retain their indigenous language, for example Lingala, Hausa or Yoruba. The other group of Black immigrants comes from India, Pakistan and Sri Lanka. Some of these students are English second-language learners, but the majority speak their mother tongue for example, Tamil, Hindi or Urdu.

1 "Black immigrants" refers to Africans who come from African countries and who are natives of any African country, or descendants of any of the people of Africa, and to Indian immigrants who hail from India, Pakistan and Sri Lanka.

2 During the apartheid era, the term "Blacks" referred to Indian, African and Coloured people of South Africa. The terms "Coloured," "White," "Indian," and "African" derive from the apartheid racial classifications of the different peoples of South Africa. The use of these terms, although problematic, has continued through the post-apartheid era in the country. In our article, we use these terms grudgingly to help present the necessary context for our work. 
Given this rich multilingual context, it is important to consider how language policy is actually implemented in schools. The Constitution of the Republic of South Africa (South Africa 1996, chap. 1, point 6) accords all 11 South African languages equal status and the Language in Education Policy (DoE 1997) promotes additive bilingualism through mother-tongue education (primarily in the early years), and gradual access to additional languages, including English. However, until 2018, English and Afrikaans still held a higher status than other languages in SA and the numerous language policies regarding SA's official languages and education (cf. Plüddemann 2015) were little more than a symbolic gesture. It is only as recently as 2019 that English has been mandated as the language of instruction in some public schools and universities. Alexander (2011) and Heugh and Prinsloo (2013) made repeated calls and sustained their stance on the valuable role of African languages and the need for multilingualism in the South African school curriculum. Nonetheless, in the last two decades, lack of political will to implement a multilingual policy and legislation has resulted in a generation of South African children who have been deprived of equity, quality education, and improved life chances (Makoe and McKinney 2014; Heugh 2015).

Recent research on the South African language policy in education has attended to the interface between multilingual pedagogies, policies, and practices among indigenous students (Heugh 2000; 2015; Makoe and McKinney 2014; Plüddemann 2015 and Probyn 2015). However, little attention has been paid to how language policy and pedagogy are experienced by multilingual immigrant learners. Furthermore, few studies have examined the language use of immigrant students in South Africa as it relates to the political and social context characterised by xenophobia and anti-immigrant sentiment. As such, the present article highlights a perspective that has been largely invisible in much research of the past by exploring the experiences of multilingual immigrant students in South Africa's Gauteng province as they engage in daily language and learning practices inside and outside the classroom. Aligning with Canagarajah's (2005) call to closely observe language practices in local contexts, this study's purpose is to help educators (in SA, but also in any multilingual/multicultural context of education) understand the experiences of immigrant students as they relate to language and identity and the way these interact with pedagogy. 


\section{Exploring the Terrain}

\subsection{Multilingual Pedagogies}

Current theories in language acquisition and teaching view multilingualism as a natural phenomenon (Agnihotri 2014), although this has not always been the case. As Canagarajah $(2013,33)$ points out, "What we have are new theories, but not new practices." Language pedagogy (and research) has begun to align with these new conceptualisations of multilingualism, favouring heteroglossic ideologies that "conceptualize bilingualism and multilingualism as a single complex competence in contrast to mastery over distinct languages" (Flores and Beardsmore 2015, 214). One such approach to language use and pedagogy is translanguaging (García 2009; Williams 1996). According to García and Wei $(2014,18)$, translanguaging refers to the multiple discursive language practices that bi/multilingual students engage in daily to make sense of their bi/multilingual worlds and to a way of capturing the expanded complex practices of speakers who "live between different societal and semiotic contexts as they interact with a complex array of speakers." This approach to language learning and use questions the boundaries between languages and emphasises the importance of understanding what speakers do with language (Makalela 2015). Pedagogical translanguaging engages teachers in fluid movement between languages as needed in order to make meaning for their students, emphasising versatile ways of communicating that "characterize multilingual communication outside the classroom" (Makalela 2015, 202), and encourage and support students' use of translanguaging (García and Wei 2014, 75).

While many studies on South African schooling contexts have focused on various issues of translanguaging in a variety of settings (e.g. Hibbert and Van der Walt 2014; Makoe and McKinney 2014; Plüddemann 2015), few studies have examined translanguaging (both for teaching and learning) from the perspective of Black immigrant students in South Africa, who often do not speak the local indigenous languages that their teachers and classmates speak. 


\subsection{Identity: Who Am I? 3}

According to Stryker and Serpe $(1982,67)$ "identities are reflexively applied cognitions that respond to the question 'Who am I'?" Ibrahim (2013) claims that identity rests on three prongs, namely "constancy and difference (who I am and who I am not); selfrepresentation and perception (what I want the world to see and what the world sees) and agency and imposition (the amount of control I have over my identity construction and the weight of social structures)." Identities are "meanings a person attributes to the self" (Burke 1980, 18) and are "complex, multi-layered, multifaceted social constructions that is a product of a wide range of societal and cultural forces" (Israelite, Liver, and Goldstein 2002, 134).

Research abounds with a variety of definitions of the concept "identity," each focusing on particular characteristics. Some claim that identities are fluid, situational, and constantly under construction, negotiation and modification (Francis and Le Roux 2011). Others see identity as a "messy," ongoing process, which involves "commitment to sexual orientation, ideological stance and vocational direction" (Marcia 1980,160 ). Yet others claim that identity is influenced by characteristics of the individual and the context (Vandeyar 2019, 458) and varies within individuals across time (Brieger 2018; Alvesson, Aschcraft, and Thomas 2008). Hall $(1996,445)$ argues that although identity "is produced and created from a personal past," it is always subject to transformation since its focus is on becoming rather than being. According to Erikson $(1968,22)$ "identities are influenced by culture, history and power and located in the core of the individual and the core of her communal culture." Norton $(2015,375)$ aptly encapsulates these varying strains of the concept of identity in her definition of identity as "multiple, a site of struggle, and changing across time and space." Identity thus evolves and changes, develops different affinities, and acquires distinctive hues throughout life.

Although the concept "identity" assumes various forms, for the purposes of this article we will focus on personal and social identity. "Personal identity" refers to the concept one develops about oneself that evolves over the course of one's life (Phinney 2008; Marcia 1980). 
"Social identity" denotes a person's sense of who they are, based on their group membership(s) (Tajfel 2010). Forming an identity, however, whether a personal or social one, is not a simple task, as it involves "negotiation between the self and complex cultural and societal forces" (Vandeyar 2019, 460).

Language plays a crucial role in identity formation. Anderson (2015) claims that "students are more likely to disconnect, disinvest, and experience educational failure if there is a disconnect between students' home identity and what is promoted by the school." The identities of immigrant students manifest themselves in numerous and multiple forms within the context of social worlds (Vandeyar 2013, 463). In the process of forming their identities, immigrant learners are highly affected by the social mirror (i.e. how society views them). An inextricable link exists between an individual's language/s and her identity (Block 2007). If learners' languages are de-valued in the larger society, and they see themselves as connected to their language (as language and identity are inherently intertwined), this leads to de-valuation of the self (Suárez-Orozco 2000). As this study explores how language shapes identity and the way the social mirror affects the identity formation of immigrant learners in South African schools, it is imperative to address the development of identity in multilingual contexts.

\subsection{Globalising the Local: Identity Development in Multilingual Contexts}

The spread of languages, literacies, and identities throughout the world over the past century has witnessed the creation of complex multilingual societies or "super-diverse" global societies (CoetzeeVan Rooy 2020). Within these multilingual contexts, children are confronted with a variety of literacy practices where different languages and ways of meaning are learnt and new identities are forged. The increasing trend of binational families and multilingual communities has also resulted in children who are born into multiple-language contexts. The identities of such children are thus enacted in culturally specific and culturally hybrid spaces. Consequently, these children learn to live in a third space (Bhabha 1994), one that is between their multiple and concurrent worlds. In this third space, the communicative 
practices of transnationals interact using different languages and communicative codes and become "transidiomatic practices" that draw on both local and distant communicative channels (Jacquemet 2005, 258). Added to this complexity is the co-existence of ideological standpoints that fuel linguistic power struggles. A multilingual person thus does not comprise two or three distinct monolinguals in one person but is, rather, a whole made up of various different linguistic parts, all of which inform identity (Ibrahim 2013). How then do multilinguals operate within educational contexts? Ibrahim (2013) uses the analogy of a chessboard to describe the management of multilingual identities. She claims it is

like playing chess: you use your quick-thinking analytical skills to move between different coloured blocks, making deliberate decisions about who you are, who you want to be or who you have to be, and what you want others to see; negotiating your way through a maze of outside perceptions, inner understandings and carefully chosen representations of self to a sometimes monochrome and fallaciously monolingual and mono-cultural world.

The construct of investment developed by Norton offers some understanding of the relationship between language and identity (Darvin and Norton 2014). According to Norton (2015, 379), investment is located at "the intersection of identity, capital, and ideology and serves as an indicator of identity and power." The navigation of learners' investments in the language and literacy practices of educational spaces becomes more complex due to their multiple and dynamic identities. Immigrant students come with specific histories, knowledges, and competencies that shape their investment in learning. Teachers and peers need to recognise this and build on their transnational literacies. Educational spaces need to become a third space which acknowledges and affirms immigrant students' fluid, multidimensional identities. When immigrant students speak, they do not just exchange information, they also reorganise a sense of who they are and how they relate to the world (Darvin and Norton 2014). Immigrant students seek to construct identities that would allow them to gain legitimacy in educational spaces they occupy (Darvin and Norton 2014). Just as identity constantly changes across time and space, the notion of investment similarly captures the fluidity and dynamism of the social world. 
Darvin and Norton $(2014,63)$ propose that teachers harness the complex identities of immigrant students through critical classroom practices and create educational spaces where these students can "fully invest in their learning, where they can find their voice and claim their right to speak." In this way, multilingual repertoires can be used as instruments that support the fostering of social cohesion by facilitating communication that enhances the building of better relationships and a deeper understanding between people in diverse settings (Coetzee- Van Rooy 2020). According to Ortega (2018, 8), when teachers remain blind to any understandings of language but "those that fit with notions of an idealized target system, unfamiliar forms of multilingual competencies are easily eradicated from the system." Ushioda (2017, 469) suggests that instead of coercion into multilingual identities of the dominant group, an important pedagogical consideration should be "a focus on multilingual speakers as the normative model of communication and instruction, and the associated promotion of ideal multilingual selves." Ibrahim $(2017,211)$ calls for a shift from a monoglossic to a heteroglossic approach in educational spaces, "foregrounding the everyday practice of local, situated, as well as transnational literacies, and recognising and valorising the ensuing hybrid language identities."

\subsection{Immigrant Learners in South Africa}

Studies on Black immigrant learners in South Africa in general are very few, but studies on immigrant students and language are even sparser, particularly studies that consider the experiences of immigrant students in multilingual schools in which indigenous languages are also mediums of instruction at certain levels of schooling (e.g. isiZulu, Sepedi). In the few studies conducted in this regard, the focus was on how school leadership addresses key challenges around the language, culture and mobility of immigrant learners (Marishane 2013). Some studies also focused on "push" and "pull" factors influencing the learning of host languages by immigrants (WildsmithCromarty and Conduah 2015,147) as well as on xenophobic tendencies related to the pronunciation and accent of English words by immigrant learners (Mahembe 2012). Research also concentrated on the congruence of school literacy with home and family literacy practices in 
immigrant households (Kajee 2011); language practices in immigrant learners' multilingual mathematics classrooms (Nkambule 2013); and processes of visibilisation and invisibilisation in the trajectory of a young immigrant in SA and the connection between language and identity (Kerfoot and Tatah 2016).

Social, cultural, economic, and personal factors affect immigrants' choices to learn a new language in what Wildsmith-Cromarty and Conduah $(2015,148)$ term a "push" and "pull" manner. The personal lives of immigrants and conditions in their country of origin constitute the "push factors." "Pull factors" comprise conditions in the host community and the attitudes of established members of that community. These "push" and "pull" factors serve to motivate immigrants to learn new indigenous African languages of their host countries not only on account of economic imperatives but also of their need for acceptance and a sense of belonging in the host country (Wildsmith- Cromarty and Conduah 2015). Vandeyar and Vandeyar (2015) have produced a large amount of scholarship on immigrant learners in South Africa. In their 2015 study, they find that most immigrant students in the social context of South African schools have to learn two additional languages: one of the indigenous African languages ${ }^{4}$ and Afrikaans (Vandeyar and Vandeyar 2015) (and sometimes English) in order to facilitate better orientation. This not only steers immigrant students into a particular course of language study, it reminds them of the social taxonomy within which they are viewed. South African schools shape how immigrant students are supposed to imagine themselves. In other studies that draw on the same data, the authors focus on identity negotiation (Vandeyar 2011; Vandeyar and Vandeyar 2011; 2012); Black female immigrant learners (Vandeyar and Vandeyar 2011); issues of race (Vandeyar 2013 and Vandeyar and Vandeyar 2017); and immigrant teachers (Vandeyar 2014). However, none of these articles focus on the connection between language and identity.

4 South Africa has nine official African languages: Sepedi, Sesotho, Setswana, Siswati, Tshivenda, Xitsonga, isiNdebele, isiXhosa, and isiZulu. 


\section{Method}

\subsection{Context}

The context of this study was limited to SA's Gauteng province. Large numbers of Black immigrant students who are diverse in terms of their countries of origin, ethnic affiliation, culture, and generational status attend many schools in the central cities of Gauteng. Data capturing for this research study occurred in 2008 and unintentionally coincided with the period of xenophobic attacks in SA (Hassim, Kupe and Worby 2008). Hence, the data capturing for this study happened during a particular tense and relevant "moment" in the history of SA. Larger societal tension fuelled by sensationalist media attention filtered into schools and had much more saliency in the formation of immigrant student identities and in everyday interactions between South African and immigrant students at schools.

\subsection{Data Collection and Participants}

This research study, which draws on a larger study (cf. Vandeyar and Vandeyar 2015), forefronts matters of language and identity that were prevalent in the data. The larger study utilised social constructivism as the meta-theoretical paradigm. The methodological paradigm was qualitative in nature and employed narrative inquiry and a case study approach in order to achieve our aim of helping educators understand the experiences of immigrant students.

The research sites were three public secondary schools that were located in the Gauteng province of SA. Reed Secondary (RS) was an urban English-medium school with a majority of Black African learners. The school was situated in the bustling and noisy city centre. This school had been established to address the need of learners who lived in the city centre. The school premises were the former district of education offices, which consisted of asbestos buildings. Steel containers were used as additional, makeshift classrooms. Portable bucket-system toilets stood in one corner of the small premises, which were emptied twice a week. The location, cramped buildings, and unhealthy sanitary conditions of RS were not conducive to teaching and learning. The school catered to 810 learners, most 
of whom came from low-income families. Seventy percent of these learners were Black African and 30\% were Black immigrants who came from various countries on the African continent. The teaching staff comprised 24 teachers, all of whom were Black African, with the exception of one Coloured ${ }^{5}$ female. The principal was a Black African male. School fees at RS were R10oo per year. Mahatma Secondary (MS) was a former English-medium Indian school that was situated in a former Indian suburb. The school catered to 840 learners, of whom 65\% were Black African learners who came from the adjoining African township; 30\% came from the adjoining informal settlement, most of whom were Black immigrant learners, and 5\% were Indian learners, mainly from low-income homes of the Indian suburb. The teaching corps comprised 75\% Indian teachers, 23\% Black African teachers, and 2\% Black immigrant teachers. The principal was an Indian male. School fees at MS were R20oo per year. Broadacres Secondary (BS) was a former White English-medium Model C school located in a former middle-upper class White suburb. It boasted a proud history of 100 years. The school formerly catered only to White learners. This school catered to 1200 learners, of whom 70\% were White and 30\% were Black (Coloured, African, Indian, and Black immigrant). Black immigrant learners comprised $5 \%$ of the $30 \%$ and were children whose parents worked in the surrounding embassies. The teaching staff comprised 68 staff members, 90\% of whom were White and 10\% Black (Indian, Coloured and African). The principal was a White female. Schools fees at BS were R18,ooo per annum.

The present article draws on semi-structured interviews with 28 immigrant students of the larger study, from countries such as Nigeria, Democratic Republic of Congo (DRC), Zimbabwe, Angola, India, Pakistan and Sri Lanka, across grades 8 to 11 at each school.

5 This term as used in South Africa derives from the apartheid era, in which it designated people of mixed ancestry. Later, it became a social category indicating an intermediate status between those identifying as being "Black" and "White." Although the legal designation and classification of "Coloured" and all restrictions based on it were abolished along with apartheid, the term still remains in use, partly because many from Coloured communities still prefer it (see IOL 2018 for an article on reactions from members of the Coloured community in South Africa to the idea of abolishing this term). 


\subsection{Data Analysis}

For the data analysis, we employed strategies from qualitative inquiry, including reading the data for a sense of the whole, documenting reflections, and combining "analytic coding with a blend of hermeneutic interpretation"-that is, thematic analysis (Kozinets 2010, 124). We created a file including all interviews, which was then uploaded to MAXQDA (qualitative research software). We used topic and open coding (Richards and Morse 2007), but specifically coded any themes related to language and identity since this was a salient part of the data that had not received enough attention in earlier studies that utilised the same data. In addition, we uploaded separate files for each of the three schools in order to compare themes across school contexts. Open coding was used to allow us to accept new concepts which arose from the data. We then utilised constant-comparative analysis (Glaser and Strauss 1967; Charmaz 2005) to aid us in examining the data. This included themes that we gradually reworked to represent the data. As a result of the holistic and cross-school analysis, five major themes related to language and identity emerged across all school contexts: how language shapes identity; erasure and loss of home languages; translanguaging; language exclusion; and language and xenophobia. Using MAXQDA, we calculated the number of instances coded for each theme. Below, we describe and analyse salient examples from each theme.

\section{Findings and Analysis}

\subsection{How Language Shapes Identity}

When asked to talk about themselves and how others identify them, participants revealed what they consider to be essential elements in their own identities. For Colette (RS), not only does she identify herself as a "quiet girl who likes friends and who likes doing her homework ...," she says that others see her as "that French girl." Given that she is a French speaker from the Democratic Republic of Congo (and not from France), she is referring to the language she speaks at home and at school with others from her country. This illustrates the way 
in which the participants value their home languages as an integral part of who they are, how they relate to the world (Darvin and Norton 2014), and how they see themselves (and others see them) in SA. For Malini (MS), who migrated from Sri Lanka to Malaysia and then India, her identity is more complex, and involves multiple nationalities as well as religion, and of course language, as seen in this excerpt from her interview: "I am an Indian ... Tamil speaking Hindu from Sri Lanka." The fact that Malini includes "Tamil speaking” as an integral part of who she is speaks volumes, given the fact that she later (see subsection 4.2) notes her frustration at not having access to Tamil in schools and that this has resulted in language loss. Hence, it is important to understand the consequences this must have for Malini, since she holds her language dear enough to include it as a central part of who she is. Below, Zahara (BS) is asked how she would identify herself or how others might identify her and responds: "I'm Zimbabwean and I'm Black and I speak Kalanga." Note that in this example, Zahara chooses first to list her original nationality, then her race, and then her home language, even though it is not present in the school curriculum. The inclusion of Kalanga in her personal/social identity marks her effort to gain legitimacy for her home language in her educational space (Darvin and Norton 2014).

As we discussed in our literature review, our identity is what makes us different from others. In the case of Colette (RS), she attends a school where there is a high population of Black immigrant learners. Perhaps for this reason, she does not identify herself according to race or even nationality, given that many others in her school are from different countries, are Black, and even from her country, the DRC. In the case of Malini, who attends a diverse school which formerly catered to South Africa's Indian population (which has been in South Africa since 1860) but currently also has newcomer students from India and South Asian countries (as well as from other ethnicities and nationalities), religion plays an important role in her life, and she attends a school with Christian, Muslim, and Hindu students. In addition, she lived in several other countries before coming to South Africa and thus she includes both India and Sri Lanka in her identity, but not Malaysia. This could be because she never gained access to school in Malaysia, which is one of the reasons her family moved from there to South Africa. On the other hand, Zahara attends a school in which 
she is one of only eight learners who are not South African born, and which has very few Black students in general. Hence, this could explain why she includes in her identity not only her nationality and language, but also her race.

Despite the different school settings, the examples above illustrate the common thread of language, which we have shown plays an integral role in shaping learner identities. Our findings align with Ibrahim's (2013) comparison of the negotiation of multilingual identities to playing chess. This involves strategising about how they want to be seen by others as well as who or how they want to be, all the while navigating the maze of outside perceptions. However, the importance of the participants' home languages as expressed by learner self-identifications or achieved identities (Suárez-Orozco 2000) is not reflected in the learning environments of the students.

\subsection{Erasure and Loss of Home Languages}

Language ideologies are people's "unconscious beliefs about language" (Palmer 2011, 104), which are closely tied to cultural identities as well as group and national politics (Irvine and Gal 2000). In our data, we found 14 examples in which learners did not mention their home languages until they were prompted multiple times by the interviewer to mention them. For example, when Mfumu (RS, from the DRC) is asked what languages he speaks, he mentions French (home) and English (school). However, when asked later about his country of origin and the languages spoken there, he adds that he speaks Lingala and Swahili. Similarly, when Zahara (BS) is asked about which languages she speaks, she replies "only English." However, later in the interview, the researcher asks whether she speaks only English at home, and she answers "Yeah, at home I speak a mixture of both English and other languages." It is only when the researcher asks her to name those languages that she identifies them as Bemba (her father's language) and Lozi (her mother's language).

The above examples illustrate the ideological process of "erasure" (Gal and Irvine 1995, 974), which "renders some persons or activities or sociolinguistic phenomena invisible." Erasure is achieved here by making the languages of school (namely, English, Afrikaans, and other colonial languages of home countries such as French) iconic of the social identities of their speakers, and hence foregrounding speakers of 
these languages as "normal" while other identities are rendered invisible. Kerfoot and Tatah (2016) refer to this as "orders of visibility," and take it as evidence of how identities become indexed by the use of certain language forms. Learners such as Mfumu and Zahara "circulate on the peripheries across local, national and transnational spaces in Africa" and "become entangled in circuits of legitimacy cycling through social and educational spaces" (Kerfoot and Tatah 2016, 18). From the time they go to school they are shown (through lack of opportunity to use their languages as resources, or by not seeing their languages valued in the school environment) that their language does not have a place there. Hence, when asked about their home languages, they do not initially include them, perhaps because they are forgetting them, perhaps because they have become complicit in the ideology that they are not important, or perhaps both. In essence, their home languages are "erased," so much so that they do not even think to name them when asked. In Zahara's case, when she first refers to them as "other languages" this shows her belief that they are not important enough to be named. Of course, learners do not come to school already believing that their languages are not important. They are taught this as part of the socialisation process in schools.

Besides unconscious attitudes and beliefs that de-value their home languages, we also found 12 instances in the data of learners that expressed sorrow or frustration about the loss of their home language. Below, saying she had to "give it up," Malini reveals how she values Tamil, and the difficulty she is having in adjusting to learning through the medium of a language she does not understand:

It's different in South Africa. In Sri Lanka all the children are the same. I learned through the medium of Tamil. Here they don't speak my language ... I had to give it up. (Malini)

Keicha notes that she is losing her French, which was the language she spoke in the DRC. "I got used to speaking English then I lost most of my French."

The above comments underscore the fact that students are aware of the subtractive language learning situation they find themselves in. Instead of gaining a new language in addition to their home languages, these languages are never treated as resources (Ruiz 1984) which could be drawn on in school environments. 


\subsection{Translanguaging}

Twenty-one instances were found in the data in which languages were viewed not as separate entities, but as single, coherent yet complex competencies that do not fit in the linguistic boxes in which monoglossic ideologies often place them (Makalela 2015). These examples from the data reveal the way in which learners naturally use "transidiomatic practices" that draw on different communicative channels (Jacquemet 2005, 258) to foster social cohesion, facilitate communication, and build relationships (Coetzee-Van Rooy 2020). The following excerpts demonstrate the way in which learners experience multilingualism when they are outside the school classroom, constructing their hybrid and complex identities on how they "sound" (Roth-Gordon 2016, 51) in addition to other identity markers. Below, Shamiso (BS) talks to the researcher about her use of Shona and English with her Zimbabwean friends:

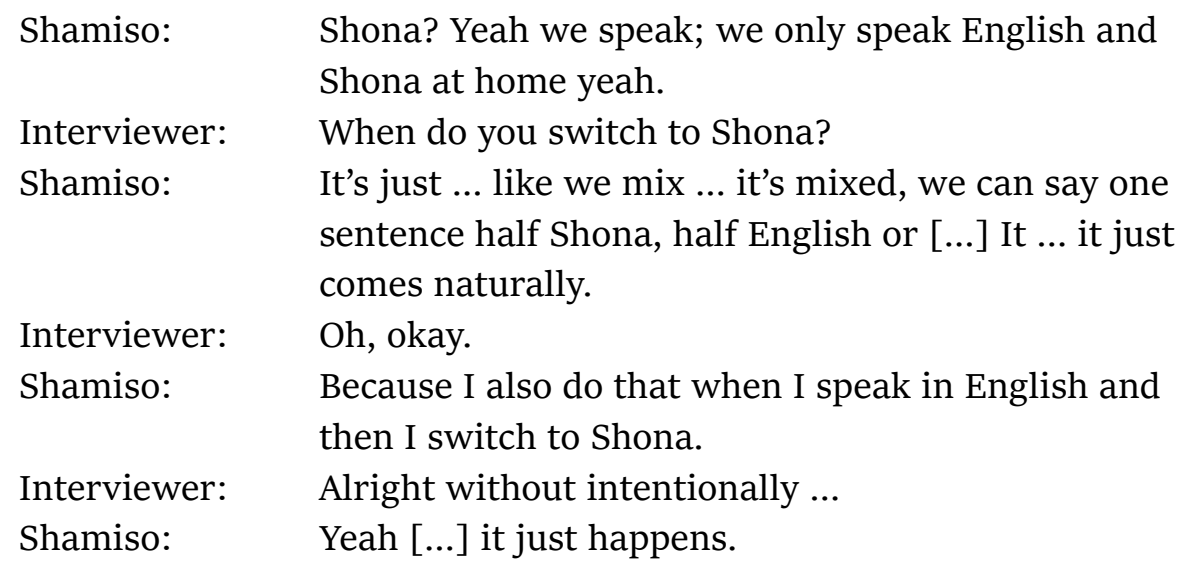

As Hibbert and Van der Walt $(2014,5)$ remind us, the type of practices described above will occur in schooling contexts (e.g., recess) whether or not they are mandated by teachers or policy makers, since students will always use the mutual languages they possess to aid in meaning-making in social contexts such as friendly conversations. The fact that Shamiso says "It just happens" illustrates the seamlessness in which multilinguals learn to make the most of their linguistic repertoires in daily life, and how the language choices they make are closely connected to their interlocutors, and to their identities as multilinguals. Below, Thandi (BS, from Zambia) talks about her friend 
from Zambia and how when the two of them are together, they just mix English with one of their Zambian languages:

... just like mix the English and one of the languages together, just a bit, but not all the time. (Thandi)

As García (2009) notes, in order to translanguage, students must have a high proficiency level in the languages that they use, as it takes a high level of skill and cognitive information to be able to do so. Thus, the above examples demonstrate how learners do this in social contexts.

\subsection{Language Exclusion}

Despite the fact that immigrant students in South Africa encounter local languages in various places (such as during recess or in the city), without specific language instruction, they often find themselves in the double-bind of attempting to learn in English-medium classes (although English is often not their home language). Teachers use translanguaging practices such as explaining difficult concepts in local languages or mixing local languages and English to help students grasp and expand their understanding of these concepts. Since in many cases these students do not receive any explicit instruction in the local language, and the teacher does not make an attempt to bring in their home language, or at least help them understand what is being said, they struggle. This was particularly evident at RS, since teachers practised translanguaging with the locally spoken Sotho language, which helped the Sotho-speaking learners. In Cerena's (RS) case, being from Nigeria, she has had experience with English, but not with Sotho:

$\begin{array}{ll}\text { Interviewer: } & \begin{array}{l}\text { Can you speak any of the indigenous African lan- } \\ \text { guages of South Africa? }\end{array} \\ \text { Cerena: } & \text { Just a little bit of Afrikaans, that is it. } \\ \text { Interviewer: } & \text { So they didn't pick up that you can't speak Sotho? } \\ \text { Cerena: } & \text { No [...].The only problem, some of the teachers spoke } \\ & \text { their own language, so I didn't understand. } \\ \text { Interviewer: } & \begin{array}{l}\text { And do you tell them that you can't understand? } \\ \text { Cerena: }\end{array} \\ & \begin{array}{l}\text { No. [...] sometimes I ask my friends to tell me what } \\ \text { they say. }\end{array}\end{array}$


When Cerena asks her friends to tell her what they say, she illustrates her learning strategy of working cooperatively with other students to gain understanding. However, the burden of understanding lies fully with her and the other student who must miss some of what is being said in order to help her. Luckily, Cerena knows English well, so she can communicate in English with her classmates, but this is not always the case.

The next example features Nelson (from Angola), whose only language before coming to South Africa was Portuguese. Talking about his teachers, Nelson (RS) remarks:

Nelson: $\quad$ They like start speaking English and then, they go into Sotho, like especially one of the students asks a question, then they answer back in Sotho yeah.

Interviewer: And, and what do you do when that happens?

Nelson: $\quad$ Well, I just stand there and just ...

Interviewer: But does this happen when they're explaining the lesson?

Nelson: $\quad H m m$ no, like it depends, like there're some teachers when they don't know what to say in English, they say it in Sotho. [...] I don't like the fact that the teachers speak Sotho in class when it's supposed to be English in class.

Nelson's comments reveal his frustration with the fact that he made great efforts to learn English, staying home for a few months to learn it before he started school. Then, when he went to class, he found that the teachers used translanguaging practices to help local students make sense of content delivered largely in English (since only 9.6\% of South African students speak English at home) (Probyn 2015, 218). Nelson feels it is unfair that he cannot understand, since he can now speak enough English to understand the English content, but the teachers move fluidly between the languages of the South African students (that they themselves know) in order to give them more meaningful learning experiences. Unfortunately for Nelson, in their translanguaging pedagogies, which are beneficial to speakers of Sotho, they have not given thought to what happens to students like him, whose home language is completely invisible in the classroom environment, creating a social mirror in which he cannot see himself. In fact, Nelson 
does not even consider that there might be a way for his teachers to help him use Portuguese just as they are using Sotho to make meaning for their students.

Hence, we have seen from these examples that pedagogical translanguaging is being applied in these schools to some degree to successfully help South African learners. However, because it is not being applied to all students, it simultaneously acts as another way of

excluding students like Nelson, and of affirming their identities as outsiders.

\subsection{Language and Xenophobia}

A final theme found in 16 instances in the data, due partly to the timing of the interviews, was xenophobia and its relation to language. In the next examples, the participants provide a glimpse into what it is like to be different in a xenophobic climate and how, in these cases, language becomes a significant semiotic marker of in-group/out-group membership when the phenotype or other characteristics (e.g., dress, religion) are the same. Below, Shamiso (BS, from Zimbabwe) notes that her classmates are keenly aware of her status as a "foreigner," and even take measures to protect her, using language as a shield against discrimination, as in this example:

Interviewer: $\quad$ Your friends here at school and everywhere else, how did they react to the xenophobia?

Shamiso: $\quad$ Yeah, they [...] I think they felt almost the same as me and they felt scared for me. They were like, they even taught me some Zulu words that if they ask you this, you must say this, and it was in a joking way ... they would teach me like because then ... to find out if you were South African, they come to you and ask you ... . What's this in Zulu?

Interviewer: $\quad$ Ah.

Shamiso: $\quad$ So if you don't know then they attack you but if you know then okay, and obviously you have to get the tones right.

Here Shamiso notes how she is learning survival skills to hide her true identity in order to protect herself in dangerous times. She not only 
recognises the lexical choices she needs to learn in order to "pass" but she has an awareness that the use of tones will also mark her as different even if she knows the words but gets the tones wrong. She is also aware of the benefits that come with learning local languages and is willing to make the effort to learn them along with the language of school. Below, Kevin (RS, Cameroon) illustrates the integral role of language in negotiating one's identity-particularly in times of heightened anti-immigrant sentiment. Here he explains the effects of the current climate on his psychological being, ${ }^{6}$ and on how he negotiates his identity with others:

Kevin: So, the thing I was scared of is one day when I go out and start talking in a different language that they never heard of, they come and do what they were doing to other people there [referring to the xenophobic violence]. So sometimes, when I go out, I don't tell people I'm from Cameroon; I tell them I'm from here.

Interviewer: Ah, do people ask you when you're walking around? Are you from South Africa, are you South African?

Kevin: Hmm.

Interviewer: If you talk to people on the street corner or somewhere?

Kevin: Hmm, that's why I'm trying to learn some of the languages, so that I can just speak to them.

Kevin's example again confirms how lack of knowledge of local languages acts as a marker of difference, and that immigrant students want to and do end up learning these languages to protect themselves and for increased social benefit. However, learning these languages takes time, and often the students do not have formal opportunities to learn these languages in school.

There were no examples of learners from MS who noted their efforts to learn African languages in order to fit in. However, some students did mention that if they knew English, they would not be called a "Paki." This is possibly because Indian learners are not assumed to

6 Readers will note that although the data for this study was collected in 2008, as this article goes to press, (sadly) xenophobic conditions still exist (see Human Rights Watch 2020). Hence, we believe our findings are still highly relevant to the current political and social climate in South Africa. 
be speakers of African languages (due to physical characteristics). Learners from this school did, however, mention the opposite problem. That is, many of their teachers (and friends) would look at them and assume they were South African Indian students, instead of newcomers, and treat them as such, ignoring the fact that they did not know English.

\section{Conclusion}

Findings from this study illuminate the ways in which multilingual immigrant children shape and negotiate their identities through language, and how learners use language in "creative ways, as they present their complex identities to the world" (Benin Benor 2016, 183). For example, we have shown the central role that language plays in how learners view themselves as different or similar to their classmates, and how language sometimes surpasses nationality, race or ethnicity as the identifying factor (e.g. "that French girl").

On the other hand, home languages were sometimes erased, as evidenced when learners were asked about the languages they speak. This meaning-making practice constructs, legitimates, and obscures relations of power (i.e. "orders of visibility"), foregrounds certain modes of knowing, being, and saying, and renders others invisible (Kerfoot and Tatah 2016, 2). In this case, the languages of school become iconic of the social identities of their speakers, and since speakers of these languages are considered "normal," the home languages of immigrant students are made invisible, even to the learner, who often needed to be prompted to mention them. Furthermore, participants were aware of the subtractive schooling contexts they frequented, and many expressed regret at the loss of their home languages which connected them to their families and their countries of origin.

Outside of the classroom, learners were shown to move fluidly between their languages, translanguaging in order to connect with different interlocutors with whom they identified. However, inside the classroom, students noted that many times translanguaging pedagogies meant to help South African speakers of indigenous languages make sense of the content inadvertently resulted in the exclusion of multilingual immigrant learners and missed opportunities for trans- 
languaging strategies to also make the classroom more inclusive for these immigrant learners.

Finally, our findings demonstrated how language can be a significant semiotic marker of in-group/out-group membership when other characteristics are the same. In these cases, language skills were often generously provided by local South African students to help immigrant learners "pass," hiding their true identities in order to protect themselves from xenophobic attacks. And, although participants revealed that many want to and do end up learning some local languages for various reasons, learning them takes time, and some immigrant learners yearn for more formal opportunities to learn these languages in school.

In general, our findings point to a number of implications for policy, practice, and research regarding schooling in South Africa. First, language policies need to account for immigrant learners. While they bring to their classrooms a myriad of cultural and linguistic assets, these students' languages are often under-utilised in school settings. Furthermore, in alignment with the plea of Du Plessis and Du Plessis (2015) to do more to increase the spheres of influence and elevate the status of indigenous languages in South Africa, we believe the same applies to immigrant learner languages, and hence both school policies and pedagogies must take this into consideration. Additionally, educators and researchers would be wise to engage in critical classroom practices (Darvin and Norton 2014) that attend to the social construction of complex identities of multilingual immigrant learners who must navigate xenophobic trends, exclusive language pedagogies, and language loss in order to create educational spaces where learners can find their voices and be heard.

Acknowledgements Data used in this article came from a research project titled "Immigrant student identities in South African schools" that was funded by SANPAD. Project number: 07/62.

\section{References}

Agnihotri, R. K. 2014. "Multilinguality, Education and Harmony." International Journal of Multilingualism 11 (3): 364-379. https://doi.org/10.1080/14790718. $\underline{2014.921181}$ 
Alexander, N. 2011. "Affirmative Action and the Perpetuation of Racial Identities in Post- Apartheid South Africa." Transformation Critical Perspectives on Southern Africa 63 (1): 92-108. https://doi.org/10.1353/trn.2007.0013

Anderson, M. 2015. "The Cost of English-Only Education." Atlantic, November 2, 2015. Accessed January 1, 2018. http://www.theatlantic.com/education/ archive/2015/11/the-costs-of-english-only-education/413494/

Alvesson, M., K. L. Aschcraft, and R. Thomas. 2008. "Identity Matters: Reflections on the Construction of Identity Scholarship in Organization Studies." Organization 15 (1): 5-28. https://doi.org/10.1177/1350508407084426

Aronin, L. 2015. "Current Multilingualism and New Developments in Multilingualism Research.” In Learning and Using Multiple Languages: Current Findings from Research on Multilingualism, edited by P. Safont Jordà and L. Portolés Falomir, 1-28. Cambridge: Cambridge Scholars Publishing.

Benin Benor, S. 2016. "Jews of Color: Performing Black Jewishness through the Creative Use of Two Ethnolinguistic Repertoires.” In Raciolinguistics: How Languages Shapes Our Ideas about Race, edited by H. S. Alim, J. R. Rickford, and A. F. Ball, 171-184. Oxford: Oxford University Press. https://doi. org/10.1093/acprof:0so/9780190625696.003.0010

Bhabha, H. 1994. The Location of Culture. London: Routledge.

Block, D. 2007. Second Language Identities. London: Continuum.

Brieger, S.A. 2018. "Social Identity and Environmental Concern: The Importance of Contextual Effects." Environment and Behaviour 51 (7): 828-855. https:// doi.org/10.1177/0013916518756988

Burke, P. J. 1980. "The Self: Measurement Requirements from an Interactionist Perspective.” Social Psychology Quarterly 43 (1): 18-29. https://doi. org/10.2307/3033745

Canagarajah, A. S. 2005. "Reconstructing Local Knowledge, Reconfiguring Language Studies." In Reclaiming the Local in Language Policy and Practice, edited by A. S. Canagarajah, 3-25. London: Routledge. https://doi. org/10.4324/9781410611840

Canagarajah, A. S. 2013. Translingual Practice: Global Englishes and Cosmopolitan Relations. New York: Routledge. https://doi.org/10.4324/9780203073889

Charmaz, K. 2005. "Grounded Theory in the 21st Century: Applications for Advancing Social Justice Studies.” In The Sage Handbook of Qualitative Research, edited by N. K Denzin and Y.S. Lincoln, 507-535. 3rd ed. London: Sage Publications.

Chiumia, S. 2016. "Factsheet: How Many International Migrants Are There in SA?" Africa Check, August 14, 2016. Last modified July 31, 2017. https://africacheck. org/factsheets/data-migrants-numbers/

Coetzee-Van Rooy, S. 2020. "Being English in Multilingual South Africa." World Englishes. https://doi.org/10.1111/weng.12475

Darvin, R. and B. Norton. 2014. "Transnational Identity and Migrant Language Learners: The Promise of Digital Storytelling." Education Matters 1 (2): 55-66. 
DoE (Department of Education). 1997. Language in Education Policy. Pretoria: Government Printer.

Du Plessis, C., and T. du Plessis. 2015. "Dealing with Disparities: The Teaching and Assessment of Official Languages at First Language Level in the Grade 12 School- Leaving Phase in South Africa." Language, Culture and Curriculum 28 (3): 209-225. https://doi.org/10.1080/07908318.2015.1083999

Erikson, E. 1968. Identity, Youth and Crisis. New York: Norton.

Flores, N., and H. B. Beardsmore. 2015. "Programs and Structures in Bilingual and Multilingual Education." In The Handbook of Bilingual and Multilingual Education, edited by W. E. Wright, S. Boun, and O. García, 205-222. Somerset, NJ: John Wiley and Sons. https://doi.org/10.1002/9781118533406.ch12

Francis, D., and A. le Roux. 2011. Teaching for Social Justice Education: The Intersection Between Identity, Critical Agency and Social Justice Education.” South African Journal of Education 31 (3): 299-311. https://doi.org/10.15700/ saje.v31n3a533

Gal, S. and J.T. Irvine. 1995. "The Boundaries of Languages and Disciplines: How Ideologies Construct Difference." Social Research 62 (4): 967-1001.

García, O. 2009. Bilingual Education in the 21st Century: A Global Perspective. Malden, MA: Wiley/Blackwell.

García, O., and L. Wei. 2014. Translanguaging: Language Bilingualism and Education. London: Palgrave Macmillan. https://doi. org/10.1057/9781137385765 4

Glaser, B., and A. Strauss. 1967. The Discovery of Grounded Theory. Chicago: Aldine.

Hall, S. 1996. "New Ethnicities.” In Stuart Hall: Critical Dialogues in Cultural Studies, edited by D. Morley and C. Kuan-Hsing, 442-451. London: Routledge.

Hassim, S., T. Kupe, and E. Worby. 2008. Go Home or Die Here: Violence, Xenophobia and the Reinvention of Difference in South Africa. Johannesburg: Wits University Press. https://doi.org/10.18772/22008114877

Heugh, K. 2000. "The Case Against Bilingual and Multilingual Education in South Africa.” PRAESA Occasional Paper 6. Cape Town: PRAESA.

Heugh, K. 2015. "Epistemologies in Multilingual Education: Translanguaging and Genre- Companions in Conversation with Policy and Practice.” Language and Education 29 (3): 280-285. https://doi.org/10.1080/09500782.2014.994529

Heugh, K. and C.H. Prinsloo. 2013. The Role of Language and Literacy in Preparing South African Learners for Educational Success: Lessons Learnt from a Classroom Study in Limpopo Province. Pretoria: HSRC Press.

Hibbert, L., and C. van der Walt, eds. 2014. Multilingual Universities in South Africa: Reflecting Society in Higher Education. Bristol: Multilingual Matters. https://doi.org/10.21832/9781783091669

Human Rights Watch. 2020. "World Report 2020: South Africa.” Human Rights Watch. Accessed July 15, 2020. https://www.hrw.org/world-report/2020/ country-chapters/south-africa 
Ibrahim, N. 2013. "Being Bilingual...Multilingual Identities." British Council, May 13, 2013. Accessed January 10, 2018. https://www.britishcouncil.fr/blog/ being-bilingual-multilingual-identities

Ibrahim N. 2017. "Developing Literacy, and Identities, in Multiple Languages.” In Literacies and Language Education, edited by B. V. Street and S. May, 211-224. Cham: Springer. https://doi.org/10.1007/978-3-319-02252-9_25

IOL 2018. "South Africans React to Tony Ehrenreich's Call to Scrap the Term 'Coloured'”' IOL, September 20, 2018. https://www.iol.co.za/news/ politics/south-africans-react-to-tony-ehrenreichs-call-to-scrap-the-termcoloured-17161067

Irvine, J. T. and S. Gal. 200o. "Language Ideology and Linguistic Differentiation." In Regimes of Language: Ideologies, Polities, and Identities, edited by P. V. Kroskrity, 35-84. Santa Fe: School of American Research Press.

Israelite, N., J. Liver, and G. Goldstein. 2002. "Hard of Hearing Adolescents and Identity Construction: Influences of School Experiences, Peers and Teachers." Deaf Education 7 (2): 134-148. https://doi.org/10.1093/deafed/7.2.134

Jacquemet, M. 2005. "Transidiomatic Practices: Language and Power in the Age of Globalization." Language and Communication 25 (3): 257-277. https://doi. org/10.1016/j.langcom.2005.05.001

Kajee, L. 2011. "Literacy Journeys: Home and Family Literacy Practices in Immigrant Households and their Congruence with Schooled Literacy." South African Journal of Education 31 (3): 434-446. https://doi.org/10.15700/saje. v31n3a545

Kerfoot, C. and Tatah, G. 2016. "Constructing Invisibility: An Immigrant Learner in South Africa." Working Papers in Urban Languages and Literacies 192. London: King's College, London. https://www.kcl.ac.uk/ecs/research/ research-centres/ldc/publications/workingpapers/abstracts/wp192

Kozinets, R.V. 2010. Netnography: Doing Ethnographic Research Online. London: Sage.

Mahembe, M. 2012. "The Psychosocial Experiences of Immigrant Learners at Primary School in the Western Cape." PhD. diss, Stellenbosch University.

Makalela, L. 2015. "Moving out of Linguistic Boxes: The Effects of Translanguaging Strategies for Multilingual Classrooms." Language and Education 29 (3): 200-217. https://doi.org/10.1080/09500782.2014.994524

Makoe, P. and C. McKinney. 2014. "Linguistic Ideologies in Multilingual South African Suburban Schools.” Journal of Multilingual and Multicultural Development 35 (7): 658-673. https://doi.org/10.1080/01434632.2014.908889

Marcia, J. E., 1980. “Identity in Adolescence." In Handbook of Adolescent Psychology, edited by J. Adelson, 159-187. New York: John Wiley and Sons.

Marishane, N. 2013. "The Right to Basic Education for All: Addressing the Educational Needs and Barriers of Immigrant Learners in South Africa." International Journal of Educational Administration and Policy Studies 5 (1): $1-7$. 
Nkambule, T. 2013. "Immigrant Learners Learning Linear Programming in Multilingual Classrooms in South Africa." PhD diss, University of South Africa.

Norton, B. 2015. "Identity, Investment, and Faces of English Internationally." Chinese Journal of Applied Linguistics 38 (4): 375-391. https://doi.org/10.1515/ cjal-2015-0025

Ortega, L. 2018. "SLA in Uncertain Times: Disciplinary Constraints, Transdisciplinary Hopes.” Working Papers in Educational Linguistics 33 (1): 1-30. https://repository.upenn.edu/wpel/vol33/iss1/1

Palmer, D. 2011. “The Discourse of Transition: Teachers' Language Ideologies within Transitional Bilingual Education Programs." International Multilingual Research Journal 5 (2): 103-122. https://doi.org/10.1080/19313152.2011.59401 9

Phinney, J.S. 2008. "Bridging Identities and Disciplines: Advances and Challenges in Understanding Multiple Identities." New Directions for Child and Adolescent Development 120: 97-109. https://doi.org/10.1002/cd.218

Plüddemann, P. 2015. "Unlocking the Grid: Language-in-Education Policy Realization in Postapartheid South Africa." Language and Education 29(3): 186-199. https://doi.org/10.1080/09500782.2014.994523

Probyn, M. 2015. "Pedagogical Translanguaging: Bridging Discourses in South African Science Classrooms." Language and Education 29(3): 218-234. https:// doi.org/10.1080/09500782.2014.994525

Richards, L. and J.M. Morse. 2012. Readme First for a User's Guide to Qualitative Methods. London: Sage.

Roth-Gordon, J. "From Upstanding Citizen to North American Rapper and Back Again: The Racial Malleability of Poor Male Brazilian Youth.” In Raciolinguistics: How Language Shapes Our Ideas about Race, edited by H. S. Alim, J. R. Rickford, and A. F. Ball, 51-64. Oxford: Oxford University Press. https://doi.org/10.1093/acprof:0so/9780190625696.001.0001

Ruiz, R. 1984. "Orientations in Language Planning." Journal of the National Association of Bilingual Education 8 (2): 15-34. https://doi.org/10.1080/08855 072.1984 .10668464

Ruiz de Zarobe, L. and Y. Ruiz de Zarobe. 2015. "New Perspectives on Multilingualism and L2 Acquisition: An Introduction." International Journal of Multilingualism 12 (4): 393-403. https://doi.org/10.1080/14790718.2015.1071 $\underline{021}$

South Africa. 1996. Constitution of the Republic of South Africa. Pretoria: Government Printer.

StatsSA (Statistics South Africa). 2018. Statistical Release Mid-Year Population Estimates. July 10, 2018. Accessed July 10, 2018. http://www.statssa.gov.za/ publications/P0302/P03022018.pdf

Stryker, S., and R.T. Serpe. 1982. "Commitment, Identity Salience and Role Behaviour: Theory and Research Example.” In Personality, Roles and Social Behavior, edited by W. Ickes and E.S. Knowles, 192-216. New York: Springer. https://doi.org/10.1007/978-1-4613-9469-3_7 
Suárez-Orozco, C. 2000. "Identities Under Siege: Immigration Stress and Social Mirroring Among the Children of Immigrants." In Cultures Under Siege: Collective Violence and Trauma, edited by A. C. G. M. Robben and M. M. SuárezOrozco, 194-226. Cambridge: Cambridge University Press.

Tajfel, H. 2010. Social Identity and Intergroup Relations. Cambridge: Cambridge University Press.

Ushioda, E. 2017. "The Impact of Global English on Motivation to Learn Other Languages: Towards an Ideal Multilingual Self." Modern Language Journal 101 (3): 469-482. https://doi.org/10.1111/modl.12413

Vandeyar, S. 2011. "Immigrant Students' Shifting Identifications in South African Schools.” International Journal of Educational Development 32 (2): 232-240. https://doi.org/10.1016/j.ijedudev.2011.03.006

Vandeyar, S. 2013. "Youthscapes: The Politics of Belonging for "Makwerekwere" Youth in South African Schools." Citizenship Studies 17 (3-4): 447-63. https:// doi.org/10.1080/13621025.2013.793079

Vandeyar, S. 2014. "Student Experiences of Immigrant Teachers in South African Schools.” Strategic Review for Southern Africa 36 (2): 156-168.

Vandeyar, S. 2019. “Unboxing 'Born-Frees': Freedom to Choose Identities.” Ensaio Avaliação e Políticas Públicas em Educação 27 (104): 456-475. https://doi. org/10.1590/s0104-40362019002702196

Vandeyar, S., and T. Vandeyar. 2011. "Articulating Cultures: Sociocultural Experiences of Black Female Immigrant Students in South African Schools." Gender and Behaviour 9 (2): 4161-4188. https://doi.org/10.4314/gab. vgi2. 72190

Vandeyar, S., and T. Vandeyar 2012. "Renegotiating Identities and Reconciling Cultural Ambiguities: Socio-Cultural Experiences of Indian Immigrant Students in South African Schools." Journal of Social Sciences 33 (2): 155-167. https:// doi.org/10.1080/09718923.2012.11893095

Vandeyar, S., and T. Vandeyar 2015. Immigrant Student Identities in South African Schools. Charlotte: Information Age. https://doi.org/10.1080/13504630.2016.1 244818

Vandeyar, S., and T. Vandeyar 2017. "Opposing Gazes: Racism and Xenophobia in South African Schools." Journal of Asian and African Studies 52 (1): 68-81. https://doi.org/10.1177/0021909614560245

Wildsmith-Cromarty, R., and A. N. Conduah. 2015. "'Push' and 'Pull' Factors Influencing the Learning of Destination Languages by Immigrants.” South African Journal of African Languages 35 (2): 147-155. https://doi.org/10.1080/ 02572117.2015.1112997

Williams, C. 1996. "Secondary Education: Teaching in the Bilingual Situation." In The Language Policy: Taking Stock, edited by C. Williams, G. Lewis and C. Baker, 39-78. Llangefni: CAI Language Studies Centre. 